\title{
Effect of Eco-Friendly Post Harvest Treatments on Decay Index of Mango Fruits Cv. Alphonso
}

\author{
Netravati $^{{ }^{*}}$, S.L. Jagadeesh ${ }^{1}$, A. Nataraja ${ }^{2}$ and G.J. Suresha ${ }^{3}$ \\ ${ }^{1}$ Department of Post-Harvest Technology, College of Horticulture, University of Horticultural \\ Sciences, Bagalkot-587 104, India \\ ${ }^{2}$ Department of Horticulture, College of Agriculture, Hassan, University of Agricultural \\ Sciences, Bengaluru-560 065, India \\ ${ }^{3}$ Department of Post-Harvest Technology, College of Horticulture, UHS Campus, GKVK Post, \\ Bengaluru -560 065, Karnataka, India \\ *Corresponding author
}

A B S T R A C T

\section{Keywords}

Mango, Decay index, Visual skin colour, Shelf life

\section{Article Info}

Accepted:

04 April 2018

Available Online:

10 May 2018
An investigation was carried out to evaluate the effectiveness of postharvest dip treatments on decay index of mango fruits cv. Alphonso. Freshly harvested and pre-cooled Alphonso mango fruits were treated with different post-harvest dip treatments and evaluated for the parameters like total soluble solids, decay index and visual skin colour change. Among different treatments, minimum $\operatorname{TSS}\left(15.60^{\circ} \mathrm{B}\right)$ was noted in hot water treated fruits, lower decay index $(0.89 \%)$ and higher score for visual skin colour (8.83) throughout the storage period was observed in azoxystrobin treated fruits as compared to untreated fruits.

\section{Introduction}

Mango is an important tropical fruit crop because of its delicious taste and flavour, attractive appearance and good market value. It is a nutritive fruit, containing most of the essential substances needed by the body (Pandey and Dinesh, 2010). Alphonso is one of the important cultivar of mango and is known as king of mango fruits. The fruits are attractive with good sugar and acid blend. Mangoes are climacteric in nature which takes 6-10 days to ripe under ambient temperature and become over-ripe and spoiled within 15 days. This short period seriously limits the long distance commercial transport of this fruit (Gomer-Lim, 1997).

Many attempts have been made to maintain the postharvest health of mango fruit which includes hot water treatment, irradiations, use of growth regulators and chemicals, storing in low temperatures, modified and controlled atmosphere storage etc. Hot water dip, a nonchemical means of improving postharvest quality in a range of horticultural products 
(Lurie, 1998) applied to pre-treat the fruits is the easiest and environment friendly (Gonzales et al., 1997). It reduces the activity of cell wall degrading enzymes, effective for fungal pathogen control and most importantly has good compatibility with the storing process (Lurie, 1998). Wax treatment acts as a selective barrier to moisture loss and gas exchange which leads to reduction of general metabolic rate and results in an improvement of fruit textural quality besides improving the fruit's appearance.

Azoxystrobin, a low residue yielding chemical with lesser MRL, is known to reduce postharvest diseases, ethylene production besides maintaining quality of the fruit (Diedhiou et al., 2014). While boric acid is known to inhibit ethylene production, ripening and disease incidence (Wang and Morris, 1993), salicylic acid is recognized to decrease the ethylene production and action, respiration rate, ripening and senescence rate, in addition to preventing cell wall degrading enzymes, oxidative stress, and inducing resistance to diseases (by acting as an elicitor) and tolerance to chilling injury (Mohammadreza and Morteza, 2010).

Chitosan is a non-toxic and biodegradable biopolymer which controls moisture movement between the fruit and surrounding environment, thus decreasing the rate of metabolism, respiration, ripening and water loss, and extending shelf life. It also has antimicrobial properties (Wang et al., 2007). Aloe vera gel-based edible coatings prevent loss of moisture and firmness, control respiratory rate, delay oxidative browning and reduce microorganism proliferation in fruits (Castillo et al., 2010).

Considerable attention has been drawn towards the potentiality of biological control agents (bioagents) and botanicals (leaf extracts) to minimize the postharvest diseases of fruit (Pang et al., 2002) and to subsequently extend the shelf life. The effect of treatment with these chemicals, polymers, bioagents and botanicals to commercial perishable plant parts vary with the crop species, variety, nature of fruit, time of treatment etc. Keeping the hurdle faced by the Alphonso mango fruits in view this experiment was framed and executed to tackle the same using different eco-friendly and edible coatings, bioagents, leaf extracts, chemicals etc.

\section{Materials and Methods}

The mature fruits of mango cv. Alphonso were harvested early in the morning and brought to the Department of Post-Harvest Technology, Arabhavi. The healthy fruits were pre-cooled in cold storage at $13 \pm 1^{\circ} \mathrm{C}$ for twelve hours and fruits were thoroughly washed in 0.2 per cent sodium hypochlorite solution for 5 minutes to remove the surface microbial load and dirt adhered to the fruit surface and air dried to remove the surface moisture. These fruits were then subjected to the following ten postharvest treatments viz., $\mathrm{T}_{1}$ : Control (untreated fruits), $\mathrm{T}_{2}$ : Hot water $\operatorname{dip}\left(50-55^{\circ} \mathrm{C}\right)$ for 5 minutes, $\mathrm{T}_{3}$ : Nipro Fresh wax (10\%) for 1 minute, $\mathrm{T}_{4}$ : Chitosan (1\%) for 1 minute, $\mathrm{T}_{5}$ : Salicylic acid $(0.2 \%)$ for 10 minutes, $\mathrm{T}_{6}$ : Boric acid $(1 \%)$ for 5 minutes, $\mathrm{T}_{7}$ : Azoxistrobin $(0.1 \%)$ for 5 minutes, $\mathrm{T}_{8}$ : Aloe vera gel (1:6 Gel: Distilled water) for 5 minutes, $\mathrm{T}_{9}$ : Solanum nigrum leaf extract $(20 \%)$ for 5 minutes and $\mathrm{T}_{10}$ : Trichoderma harzianum $(10 \mathrm{~g} / \mathrm{l})$ for 5 minutes. After imposition of the dip treatments detailed above, the fruits were surface dried and were packed in the CFB boxes. Each treatment consisted of 24 fruits and was replicated thrice. Thus, there were 24 fruits in each box packed in 2 layers. All the boxes were then stored in cold storage maintained at $13 \pm 1^{\circ} \mathrm{C}$ for 28 days. At the end of 28 days of cold storage, the fruits were taken out from the cold room and held at room temperature for 7 days. 


\section{Total soluble solids}

The juice extracted by squeezing the homogenized fruit pulp through muslin cloth was used to measure the TSS. It was determined by using ERMA hand refractometer, replicated three times and the mean was expressed in ${ }^{\circ} \mathrm{B}$.

\section{Decay index}

The degree of decay index in fruits was indicated based on external damage on the skin. The decay score was assessed by the percentage of total surface area affected, where $0=$ no visible decay area, $1=1-10 \%$ decay area, $2=11-25 \%$ decay area, $3=26-$ $50 \%$ decay area, $4=51-75 \%$ decay area, and 5 $=>75 \%$ decay area. It was calculated by using the formula given below.

Decay Index $=\frac{\text { Total score of decay on fruits }}{\text { Number of fruits observed } \mathrm{x} \text { Maximum score }} \times 100$

\section{Skin appearance}

Skin appearance was evaluated using nine point hedonic scale using the scores like poor, fair, good, very good and excellent.

\section{Results and Discussion}

\section{TSS}

In the present investigation, irrespective of the treatments, there was a general increase in the TSS of mangoes up to the end of experimental period (Table 1). At the end of 28 days of cold storage and in the subsequent 1 week ambient storage, the treatment $\mathrm{T}_{7}$ (Azoxystrobin @ $0.1 \%$ for 5 minutes) recorded the maximum TSS of $21.73^{\circ} \mathrm{B}$. The minimum TSS was found in hot water treated fruits $\left(16.33^{\circ} \mathrm{B}\right)$ at 28 days of cold storage and in the wax treated fruits $\left(18.10^{\circ} \mathrm{B}\right)$ at the end of ambient storage. The increase in TSS and sugars during storage may possibly be due to breakdown of complex organic metabolites into simple molecules or due to hydrolysis of starch into sugars. During ripening, TSS and sugar levels within the fruit tend to increase due to either sugar importation from the plant or mobilization of starch reserves within the fruit, depending on the fruit type and whether the fruit is ripened on or off the plant (Whiting, 1970).

During ripening, the accumulated starch hydrolyses as a result of amylase activity leading to the formation of sugars. Surprisingly, control fruits and hot water treated fruits also recorded lower TSS. This might be probably due to ineffective conversion of starch in to sugars in these treatments. Ripening with hot water treatment could be promoted or adversely affected (Paull, 1995). Hot water treatments have been shown to delay fruit softening during storage in peaches and nectarines (Zhou et al., 2002 and Malakou and Nanos, 2005) and may not be favourable in all aspects of fruit ripening. Similar results were obtained by Molla et al., (2011), Raheel and Aman (2007), Waskar and Gaikwad (2005) and Waskar (2005) in mango; Varit and Songsin (2011) and Nurul and Mosharraf (2012) in banana.

Comparatively, delayed increase in TSS over the storage period in the wax and chitosan treated fruits could be attributed to retarded conversion of starch to sugars which in turn is due to the effect of surface coatings. Similar results with wax application were noticed by Waskar and Gaikwad (2005) and Singh et al., (2012) in mango; Sariful et al., (2001) in banana; Mahajan and Rupinder (2014) and Mahajan et al., (2013) in kinnow mandrin; Sidhu et al., (2009) in pear fruits and Bishnoi et al., (2008) in apple fruits. The authors Kequian et al., (2012) in guava; Asgar et al., (2011) in litchi; and Kittur et al., (2001) in banana and mango observed delayed increase in TSS and sugars in chitosan treated fruits. 
Table.1 Effect of postharvest treatments on total soluble solids $\left({ }^{\circ} \mathrm{B}\right)$ of mango cv. Alphonso stored under cold $\left(13 \pm 1^{\circ} \mathrm{C}, 2\right.$ days) and ambient conditions ( 7 days). Similar alphabets within the column represents non-significant differences at $(\mathrm{p}<0.05)$ probability level according into Duncan's multiple range test

\begin{tabular}{|c|c|c|c|c|c|c|}
\hline \multirow[t]{3}{*}{ Treatments } & \multicolumn{5}{|c|}{ TSS $\left({ }^{0} \mathbf{B}\right)$} & \multirow[t]{3}{*}{ Mean } \\
\hline & \multicolumn{5}{|c|}{ Storage (Days) } & \\
\hline & 7 & 14 & 21 & 28 & $28+7$ & \\
\hline $\mathbf{T}_{1}$ & 13.67 & $14.73^{\mathrm{cd}}$ & $16.00^{b c}$ & $16.83^{\mathrm{cd}}$ & $18.33^{\mathrm{cd}}$ & $15.91^{b c}$ \\
\hline $\mathbf{T}_{2}$ & 13.00 & $14.67^{\mathrm{cd}}$ & $15.50^{c}$ & $16.33^{\mathrm{d}}$ & $18.50^{\text {bcd }}$ & $15.60^{c}$ \\
\hline $\mathbf{T}_{3}$ & 13.67 & $13.93^{\mathrm{d}}$ & $15.33^{c}$ & $17.13^{\mathrm{cd}}$ & $18.10^{\mathrm{d}}$ & $15.63^{c}$ \\
\hline $\mathbf{T}_{4}$ & 13.00 & $15.00^{\mathrm{cd}}$ & $16.73^{\mathrm{abc}}$ & $18.00^{\mathrm{bc}}$ & $19.13^{\mathrm{bcd}}$ & $16.40^{b c}$ \\
\hline $\mathbf{T}_{5}$ & 13.50 & $15.33^{\mathrm{abcd}}$ & $15.83^{c}$ & $17.47^{\text {bcd }}$ & $18.40^{\text {bcd }}$ & $16.10^{b c}$ \\
\hline $\mathrm{T}_{6}$ & 15.33 & $16.50^{\mathrm{ab}}$ & $18.00^{\mathrm{a}}$ & $19.07^{\mathrm{ab}}$ & $20.53^{a b c}$ & $17.89^{a}$ \\
\hline $\mathbf{T}_{7}$ & 12.67 & $15.10^{\text {bcd }}$ & $17.83^{\mathrm{a}}$ & $20.07^{\mathrm{a}}$ & $21.73^{\mathrm{a}}$ & $17.48^{\mathrm{a}}$ \\
\hline $\mathrm{T}_{8}$ & 14.17 & $16.67^{\mathrm{a}}$ & $17.33^{\mathrm{ab}}$ & $18.07^{\mathrm{bc}}$ & $20.67^{\mathrm{ab}}$ & $17.38^{\mathrm{a}}$ \\
\hline $\mathrm{T}_{9}$ & 14.33 & $15.67^{\mathrm{abc}}$ & $16.77^{\mathrm{abc}}$ & $17.00^{\mathrm{cd}}$ & $18.73^{\mathrm{bcd}}$ & $16.50^{b}$ \\
\hline $\mathbf{T}_{10}$ & 15.00 & $16.00^{\mathrm{abc}}$ & $16.67^{\mathrm{abc}}$ & $18.33^{b c}$ & $20.67^{\mathrm{ab}}$ & $17.33^{\mathrm{a}}$ \\
\hline Mean & 13.83 & 15.36 & 16.60 & 17.83 & 19.48 & 16.62 \\
\hline S.Em \pm & - & 0.50 & 0.50 & 0.55 & 0.79 & 0.61 \\
\hline C.D@ 5\% & NS & 1.49 & 1.48 & 1.62 & 2.33 & 1.71 \\
\hline
\end{tabular}

Table.2 Effect of postharvest treatments on skin colour and decay index of mango cv. Alphonso stored under cold $\left(13 \pm 1{ }^{\circ} \mathrm{C}, 28\right.$ days) and ambient conditions (7 days). Similar alphabets within the column represents non-significant differences at $(\mathrm{p}<0.05)$ probability level according into Duncan's multiple range test

\begin{tabular}{|c|c|c|c|c|c|c|c|c|}
\hline \multirow[t]{3}{*}{ Treatments } & \multirow{2}{*}{\multicolumn{3}{|c|}{$\begin{array}{c}\text { Skin colour (Score out of 9) } \\
\text { Storage (Days) }\end{array}$}} & \multirow[t]{3}{*}{ Mean } & \multirow{2}{*}{\multicolumn{3}{|c|}{$\begin{array}{c}\text { Decay index } \\
\text { Storage (Days) }\end{array}$}} & \multirow[t]{3}{*}{ Mean } \\
\hline & & & & & & & & \\
\hline & 21 & 28 & $28+7$ & & 21 & 28 & $28+7$ & \\
\hline$T_{1}$ & $6.50^{\mathrm{ab}}$ & $7.67^{\mathrm{ab}}$ & $7.67^{\mathrm{cd}}$ & $27.20^{\mathrm{a}}$ & 2.67 & $4.00^{\mathrm{a}}$ & 6.67 & $4.45^{\mathrm{a}}$ \\
\hline $\mathbf{T}_{2}$ & $6.80^{\mathrm{ab}}$ & $7.67^{\mathrm{ab}}$ & $8.75^{\mathrm{a}}$ & $22.67^{b c}$ & 1.33 & $2^{a b c}$ & 3.33 & $2.22^{b c d}$ \\
\hline $\mathbf{T}_{3}$ & $5.67^{\mathrm{bc}}$ & $7.33^{\mathrm{ab}}$ & $8.17^{\mathrm{abc}}$ & $24.07^{\text {abc }}$ & 0.67 & $1.33^{\mathrm{bc}}$ & 3.33 & $1.78^{\mathrm{cd}}$ \\
\hline $\mathbf{T}_{4}$ & $5.67^{\mathrm{bc}}$ & $5.67^{\mathrm{bc}}$ & $7.83^{\mathrm{bcd}}$ & $17.07^{d}$ & 0.67 & $0.67^{c}$ & 1.33 & $0.89^{d}$ \\
\hline$T_{5}$ & $4.67^{\mathrm{c}}$ & $4.33^{c}$ & $7.17^{d}$ & $26.87^{a}$ & 2.00 & $3.33^{\mathrm{ab}}$ & 4.67 & $3.33^{\mathrm{abc}}$ \\
\hline$T_{6}$ & $7.33^{\mathrm{a}}$ & $7.83^{\mathrm{a}}$ & $8.50^{\mathrm{ab}}$ & $25.00^{a b}$ & 0.67 & $1.33^{\mathrm{bc}}$ & 3.33 & $1.78^{\mathrm{cd}}$ \\
\hline $\mathrm{T}_{7}$ & $7.83^{\mathrm{a}}$ & $8.17^{\mathrm{a}}$ & $8.83^{\mathrm{a}}$ & $13.87^{d}$ & 0.67 & $1.33^{\mathrm{bc}}$ & 2.67 & $1.56^{d}$ \\
\hline$T_{8}$ & $6.75^{\mathrm{ab}}$ & $7.92^{a}$ & $8.05^{\mathrm{abc}}$ & $21.20^{c}$ & 1.33 & $3.33^{\mathrm{ab}}$ & 6.00 & $3.55^{\mathrm{ab}}$ \\
\hline$T_{9}$ & $6.50^{\mathrm{ab}}$ & $6.67^{\mathrm{ab}}$ & $7.70^{\mathrm{bcd}}$ & $22.73^{b c}$ & 0.67 & $0.67^{c}$ & 3.33 & $1.56^{\mathrm{d}}$ \\
\hline $\mathrm{T}_{10}$ & $6.25^{\mathrm{abc}}$ & $6.83^{\mathrm{ab}}$ & $8.41^{\mathrm{abc}}$ & $21.87^{b c}$ & 0.60 & $1.33^{\mathrm{bc}}$ & 4.67 & $2.22^{\mathrm{bcd}}$ \\
\hline Mean & 6.40 & 7.01 & 8.11 & 22.25 & 1.14 & 1.93 & 3.93 & 2.33 \\
\hline S.Em \pm & 0.54 & 0.72 & 0.27 & 2.58 & - & 0.70 & - & 0.89 \\
\hline C.D@ 5\% & 1.60 & 2.13 & 0.81 & 7.26 & NS & 2.07 & NS & 2.49 \\
\hline
\end{tabular}




\section{Skin appearance}

\begin{tabular}{|c|c|}
\hline Scale & Skin colour \\
\hline 1 & Poor \\
\hline 3 & Fair \\
\hline 5 & Good \\
\hline 7 & Very good \\
\hline 9 & Excellent \\
\hline
\end{tabular}

Plate.1 Picture showing burning damage on the fruit caused due to higher concentration of salicylic acid

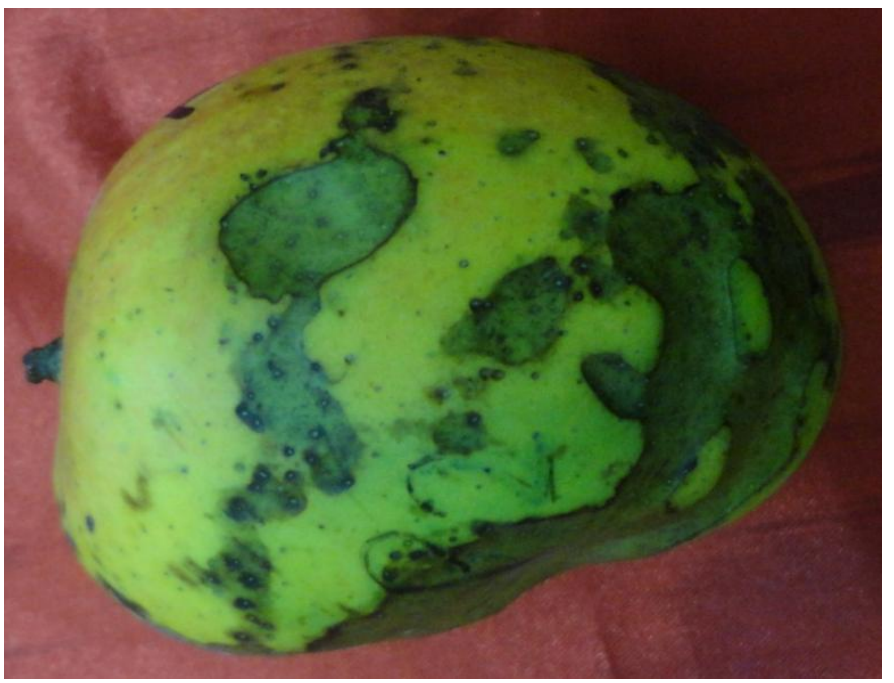

\section{Skin colour}

In this investigation, score for skin colour increased with the increase in storage time indicating attractive colour development and progress of ripening along the storage period (Table 2). Maximum score for skin colour was noted in the treatment $\mathrm{T}_{7}$ (7.83 at 21 days, 8.17 at 28 days and 8.83 at $28+7$ days after storage). This may be attributed to the effectiveness of fungicide keeping the skin surface spot free and therefore attractive. Boric acid treatment $\left(\mathrm{T}_{6}\right)$ also resulted in higher score for skin colour (7.33 at 21 days, 7.83 at 28 days and 8.50 at $28+7$ days after storage). Boron is an essential microelement and has important physiological functions for plant growth (Xuan et al., 2001 and Simoglou and Dordas, 2006) and quality improvement in fruit (Plich and Wójcik, 2002). However, poor skin colour was associated with salicylic acid $\left(\mathrm{T}_{5}\right)$ with the overall mean score of 5.39. It may be attributed to the burning damage caused to the fruit skin at 0.2 per cent concentration thus spoiling the skin colour (Plate 1).

\section{Decay index}

The decay index of mango fruits increased as the storage duration progressed in all the treatments (Table 2). However, there was no decay observed in any of the treatments until the end of 3 weeks. After 28 days of cold storage, significantly lower and similar decay rate $(0.67 \%)$ was observed in the treatments $\mathrm{T}_{4}$ (Chitosan (1\%) for 1 minute) and $\mathrm{T}_{9}$ (Solanum nigrum leaf extract (20\%) for 5 minutes). On the other hand, significantly higher decaying observed in untreated fruits $(4.00 \%)$ was nonsignificantly followed by $\mathrm{T}_{5}(3.33 \%)$ and $\mathrm{T}_{8}$ 
(Aloe vera gel 1:6 - Gel: Distilled water for 5 minutes) $(3.33 \%)$. However, at the end of ambient storage $(28+7$ days) there were no significant differences noticed among the treatments. The effect of storage temperature on the development of fruit rot is well known. The reduction in disease incidence at low temperatures should be rather linked to both inhibition of fungal growth as well as slow down of fruit ripening process. According to Bezuidenhout (1983), temperatures are the main determinant of the start of active development for latent infections of anthracnose fungi. The overall mean decay index was higher in control fruits followed by $\mathrm{T}_{5}$ and $\mathrm{T}_{8}$. On the other hand, lower decay index was observed in the treatments $T_{4}, T_{7}$ and $T_{9}$. It may be attributed to the antimicrobial nature of chitosan, antifungal nature of azoxystrobin and antimicrobial nature of Solanum nigrum leaf extract.

\section{References}

Asgar, A., Mahmud, T. M., Muhammad, K. S., Yasmeen, S. 2011. Effect of chitosan coatings on the physicochemical characteristics of Eksotika II papaya (Carica papaya L.) fruit during cold storage. Food Chemistry, 124: 620-626.

Bezuidenhout, J. J. 1983. The relationship between ripening temperature, softening rate and internal anthracnose of avocado. South African Avocado Grower's Association year book, 6:51-53.

Bishnoi, A., Chawla, H. M., Rani, G., Saxena, R., Sreenivas, V. 2008. Effect of formulation derived from terpenoidal oligomer on shelf-life of apples without refrigeration. J. Food Sci. Technol., 45(5): 412-415.

Castillo, S., Navarro, D., Zapata, P. J., Guillen, F., Valero, D., Serrano, M., MartinezRomero, D. 2010. Antifungal efficacy of Aloe vera in vitro and its use as a preharvest treatment to maintain postharvest table grape quality. Postharvest Biol. Technol., 57: 183-188.

Diedhiou. P. M., Mbaye, N., Rokhaya. F., Samb, P. I. 2014. Field tests of fungicides against post-harvest rot of mangoes in Senegal. Intl. J. of Sci. Environment and Technol., 3(2): 597-606.

Gomer-Lim, M. A. 1997. Postharvest physiology. The Mango: Botany, production and uses. Cab Intl. New York, pp. 425-446.

Gonzales-Aguilar, G., Zacarias, L., Mulas, M., Lafuente. M.T. 1997. Temperature and duration of water dips influence chilling injury, decay and polyamine content in Fortune mandarins. Postharvest Biol. Technol., 12: 61-69.

Kequian, H., Jianghui, X., Lubin, Z., Dequan, S., Deqiang, G. 2012. Effects of chitosan coating on postharvest life and quality o guava (Psidium guajava L.) fruit during cold storage. Scientia Horticulturae. 144: 172-178.

Kittur, F. S., Saroja, N. S., HabibunnisaTharanathan, R. N. 2001. Polysaccharide based composite coating formulations for shelf-life extension of fresh banana and mango. Eur. Food Res. Technol., 213: 306-311.

Lurie, S., 1998, Postharvest heat treatments. Postharvest. Biol. Technol. 14: 257-269.

Mahajan, B. V. C., Dhillon, W. S. and Mahesh, K. 2013. Effect of surface coatings on the shelf life and quality of kinnow fruits during storage. J. Postharvest Technol., 1(1): 7-15.

Mahajan. B. V. and Rupinder. S., 2014, Influence of coatings on postharvest physiology and shelf life of kinnow fruits under super market conditions. J. Postharvest Technol., 2(1): 37-44.

Malakou, A., Nanos, G. D. 2005. A combination of hot water treatment and modified atmosphere packaging maintains quality of advanced maturity 'Caldesi 2000' nectarines and 'Royal glory' peaches. Postharvest biol. Tech., 38: 106-114.

Mohammadreza, A., Morteza, S. A. 2010. Impact of salicylic acid on post-harvest physiology of horticultural crops. Trends in Food Science \& Technology, 21: 502509. 
Molla, M. M., Islam, M. N., Muqit, M. A., Ara, K. A., Talukder, M. A. H. 2011. Increasing shelf life and maintaining quality of mango by postharvest treatments and packaging technique. J. Ornamental and Hort. Plants. 1(2): 73-84.

Nurul, M. A., Mosharraf, M. H. 2012. Reduction of postharvest loss and prolong the shelf-life of banana through hot water treatment. J. Chem. Engg., 27(1): 42-47.

Pandey, S. A., Dinesh, M. R. 2010. Mango, ICAR, New Delhi.

Pang, X., Qun Zhang, Z. Q., Huang Xue, M. 2002. Biological control of postharvest diseases of fruits and vegetables. J. Trop. Subtrop. Bot., 10: 186-192.

Paull, R. E. 1995. Pre-harvest factors and the heat sensitivity of field-grown ripening papaya fruit, Postharvest Biol. Technol., 6: 167-175.

Plich, H., Wójcik, P. 2002. The effect of calcium and boron foliar application on postharvest plum fruit quality. Acta Hort. 594: 445-451.

Raheel, A., Aman, U. M. 2007. Hot water treatment affects ripening quality and storage life of mango (Mangifera Indica L.). Pak. J. Agri. Sci., 44(2): 304- 311.

Sariful, M. I., Saiful. M. I., Fazlul, K. A. 2001. Effect of post-harvest treatments with some coating materials on the shelf life and quality of banana, Pak. J. Biol. Sci., 4 (9): 1149-1152.

Sidhu, G. S., Dhillon, W. S., Mahajan, B. V. C. 2009. Effect of waxing and packaging on storage of pear cv. Punjab Beauty. Indian J. Hort., 66(2): 239-244.

Simoglou, K. B., Dordas, C. 2006. Effect of foliar applied boron, manganese and zinc on tan spot in winter durum wheat. Crop Prot., 25: 657-663.
Singh, A. K., Singh, C. P., Kushwaha, P.S., Chakraborty, B. 2012. Efficacy of postharvest treatments on fruit marketability and physico-chemical characteristics of Dashehari mango. Progressive Hort., 44(2): 215-219.

Varit, S., Songsin, P. 2011. Effects of hot water treatments on the physiology and quality of 'Kluai Khai' banana. Intl Food Res. J., 18(3):1013-1016.

Wang, J., Wang, B., Jiang, W., Zhao, Y. 2007. Quality and shelf life of mango (Mangifera indica L. cv. Tainong) coated by using chitosan and polyphenols. Food Sci. Technol. Intl., 13(4): 317-322.

Wang, S., Morris, S. C. 1993. Effects of borax and guazatine on ripening and postharvest diseases of tomato (cv. Floradade). Acta Hort., 343(1): 331-333.

Waskar, D. P. 2005. Hot water treatment for disease control and extension of shelf life of 'Kesar' mango (Mangifera indica L.) fruits. Acta Hort., 682: 1319-1324.

Waskar, D. P., Gaikwad, R. S. 2005. Effect of various postharvest treatments on extension of shelf life of Kesar mango fruits. Indian J. Agric. Res., 39 (2): 95102.

Whiting, G. C. 1970. Sugars. In: The Biochemistry of Fruits and their Products. Ed. Hulme, A. C., Academic Press, London. 1: 1.

Xuan, H., Streif, J., Bangerth, F. 2001. Effect of boron applications on physiological disorders in 'conference' pears during CA-storage. Acta Hort., 553: 249-251.

Zhou, T., Xu, S., Sun, D., Wanga, Z. 2002. Effects of heat treatment on postharvest quality of peaches. Postharvest Biol. Techol., 54: 17-22.

\section{How to cite this article:}

Netravati, S.L. Jagadeesh, A. Nataraja and Suresha, G.J. 2018. Effect of Eco-Friendly Post Harvest Treatments on Decay Index of Mango Fruits Cv. Alphonso. Int.J.Curr.Microbiol.App.Sci. 7(05): 17. doi: https://doi.org/10.20546/ijcmas.2018.705.001 